\title{
Microbiological testing of devices used in maintaining peripheral venous catheters $^{1}$
}

\author{
Fernanda de Paula Rossini² \\ Denise de Andrade ${ }^{3}$ \\ Lissandra Chaves de Sousa Santos ${ }^{4}$ \\ Adriano Menis Ferreira ${ }^{5}$ \\ Caroline Tieppo ${ }^{6}$ \\ Evandro Watanabe ${ }^{7}$
}

Objective: to evaluate the use of peripheral venous catheters based on microbiological analysis of devices (dressing and three-way stopcocks) and thus contribute to the prevention and infection control. Methods: this was a prospective study of microbiological analysis of 30 three-way stopcocks (external surfaces and lumens) and 30 dressing used in maintaining the peripheral venous catheters of hospitalized adult patients. Results: all external surfaces, $40 \%$ of lumens, and $86.7 \%$ of dressing presented bacterial growth. The main species isolated in the lumen were $50 \%$ coagulase-negative Staphylococcus, 14.3\% Staphylococcus aureus, and $14.3 \%$ Pseudomonas aeruginosa. Fifty nine percent of multidrug-resistant bacteria were isolated of the three-way stopcocks, $42 \%$ of the lumens, and $44 \%$ of the dressing with a predominance of coagulase-negative Staphylococcus resistant to methicillin. Besides, $18 \%$ gram-negative bacteria with resistance to carbapenems were identified from multidrug-resistant bacteria on the external surfaces of the three-way stopcocks. Conclusion: it is important to emphasize the isolation of coagulase-negative Staphylococcus and gram-negative bacteria resistant to methicillin and carbapenems in samples of devices, respectively, which reinforces the importance of nursing care in the maintenance of the biologically safe environment as well as prevention and infection control practices.

Descriptors: Cross Infection; Vascular Access Devices; Catheters; Contamination; Bacteria; Drug Resistance, Microbial.

\footnotetext{
${ }_{1}^{1}$ Paper extracted from Doctoral Dissertation "Residence time of the peripheral venous catheter and the bacterial growth in catheter and connector: subsidies for prevention of adverse events", presented to Escola de Enfermagem de Ribeirão Preto, Universidade de São Paulo, WHO Collaborating Centre for Nursing Research Development, Ribeirão Preto, SP, Brazil.

2 PhD, RN, Hospital das Clínicas, Faculdade de Medicina de Ribeirão Preto, Universidade de São Paulo, Ribeirão Preto, SP, Brazil.

${ }^{3} \mathrm{PhD}$, Associate Professor, Escola de Enfermagem de Ribeirão Preto, Universidade de São Paulo, WHO Collaborating Centre for Nursing Research Development, Ribeirão Preto, SP, Brazil.

${ }^{4}$ Doctoral student, Escola de Enfermagem de Ribeirão Preto, Universidade de São Paulo, WHO Collaborating Centre for Nursing Research Development, Ribeirão Preto, SP, Brazil.

${ }^{5} \mathrm{PhD}$, Associate Professor, Universidade Federal do Mato Grosso do Sul, Três Lagoas, MS, Brazil.

${ }^{6}$ Pharmacy-Biochemistry, Hospital Regional do Mato Grosso do Sul, Campo Grande, MS, Brasil.

7 PhD, Professor, Faculdade de Odontologia de Ribeirão Preto, Universidade de São Paulo, Ribeirão Preto, São Paulo, Brasil.
}

\section{How to cite this article}

Rossini FP, Andrade D, Santos LCS, Ferreira AM, Tieppo C, Watanabe E. Microbiological testing of devices used in maintaining peripheral venous catheters. Rev. Latino-Am. Enfermagem. 2017;25:e2887. [Access †千 †]; Available in: DOI: http://dx.doi.org/10.1590/1518-8345.1528.2887. month day year 


\section{Introduction}

Health care in the hospital environment is constantly challenged by infections, which result in increases in morbidity and mortality, length of stay, and costs, especially considering the consumption of antibiotics and laboratory tests. Given the proportions, these infections represent one of the largest public health problems, which is aggravated by the presence of resistant strains, since they challenge scientific and technological advances and therefore catch the attention of professionals, researchers, and organizations looking for effective prevention and control measures ${ }^{(1-3)}$.

Risk factors for infection is an indicator that deserves careful analysis and elucidation in the management of aseptic techniques. This analysis represents a challenge, given variability of risks and diversity of behaviors and recommendations. In this sense, the need emerges to objectively identify the possible risks of contamination and colonization ${ }^{(4-5)}$.

The use of intravascular catheters constitutes a vital strategy for clinical practice and effectiveness of treatments ${ }^{(6-8)}$. It is worth mentioning that peripheral venipuncture is not free of complications, since it is an invasive procedure of high frequency done most of the time in a hospital setting, which is a place that presents risks of contamination and colonization, and which requires appropriate conduct in care of catheters.

The maintenance of peripheral venous catheters is a complex topic and requires following a number of technical aseptic conformities and operational principles with a view toward safety and the prevention and control of infection.

The incidence of phlebitis and infections associated with peripheral venous catheters is relatively low, but the possibility of underestimation of data should be pointed out, especially considering the high frequency with which this procedure is done in daily routine health care. Catheter-related bacterial infections prolong hospitalization and increase the cost of treatment, besides presenting attributable mortality rates in the range between $10 \%$ to $25 \%{ }^{(6,9)}$.

According to these questions: Is it possible to isolate bacteria from samples of devices (dressing and three-way stopcocks - 3WSCs) used in peripheral venous access? What is the prevalence and sensitivity profile of the isolated bacteria? Moreover, are these bacteria resistant to carbapenems?

Therefore, this research attempts to evaluate the microbiological conditions of devices (dressing and
3WSCs) used in peripheral venous access and thus, contribute to the prevention and control of infection.

\section{Methods}

This is a microbiological clinical study done on the 3WSCs and dressing used in the maintenance of peripheral venous catheters (PVC) type abbocath used in hospitalized patients.

Samples from the devices were collected for adult patients admitted to the medical and neurological clinical specialty of a public university hospital inpatient for highly complex clinical emergency care. For 60 devices (30 dressing and 30 3WSCs), 90 microbiological processes were carried out, 30 from the external surfaces, 30 from the lumens of the 3WSCs, and 30 from the dressing. The devices analyzed were collected after discontinuing use of the intravenous devices (due to doctor's orders, obstruction, infiltration, the presence of classic phlebitis signs of pain, edema, hyperthermia, and local hyperemia), or in cases where there was a need to change the dressing of the access considering the conditions of integrity and humidity. The removal of these devices from the patients was done exclusively by nurses working in the unit. We believe that removal according to hospital routine preserved the microbiological conditions of the real situation of hospital care. Any type of contamination was avoided during the removal and transfer of the samples to their sterile packaging. The area of the dressing in contact with the catheter insertion site was marked externally to show where the microbiological collection should be made.

Furthermore, information was collected as to the date of the peripheral venipuncture that was on the dressing and description of the general conditions in terms of dirtiness or presence of blood (evaluation of the macroscopic condition of the dressing). The research was conducted with the approval of the Research Ethic Committee (37194214.1.0000.5393).

\section{Inclusion criteria}

The evaluation included 3WSCs used in maintaining the PVC and sterile dressing made of soft fabric backed with rayon and polyester with hypoallergenic acrylate adhesive, water-resistant, non-owcclusive, and made of hypoallergenic transparent film with vapor permeability.

\section{Microbiological processing}

The collection of biological material from the dressing was done by friction on the inner surface 
with a swab moistened with saline solution, which was in contact with the catheter insertion site (previously defined area) for 30 seconds and in three directions. Then the swab was transferred to a sterile test tube (25 mm x $125 \mathrm{~mm}$ ) containing $20 \mathrm{~mL}$ of Tryptic Soy Broth (TSB). For the culture from the 3WSCS's lumen, a syringe and sterile gloves were used to carry out a flush of $10 \mathrm{~mL}$ of TSB through each of the two routes of the 3WSCS into a sterile test tube $(25 \times 125 \mathrm{~mm})$ with glass beads. For the culture of the external surface the 3WSCS was flushed with the routes closed into a sterile vial with $200 \mathrm{~mL}$ of TSB.

After these procedures, homogenization was carried out on the samples using an AP-56 tube shaker (Phoenix, Brazil) during 1 minute and then the samples were incubated (Quimis, Brazil) at $37^{\circ} \mathrm{C}$ for 24 hours up to 14 days (sterility test). The initial microbiological analyses were performed in a Class II Biological Safety Cabin Model Bio Seg 12 (VECO Group, Brazil) in the microbiology laboratory. After incubation, the samples were seeded on Petri plates $(15 \times 90 \mathrm{~mm})$ with selective culture media (Mannitol, MacConkey, and Cetrimide) and processed in a VITEK ${ }^{\circledR} 2$ Compact automated system (Biomérieux, France) for bacterial identification and sensitivity profile.

\section{Results}

Of the total of 90 microbiological analyses, the samples from the lumen of the 3WSCs had growth positive levels of $40 \%$ in the TSB culture medium. The samples from the dressing showed $86.7 \%$ of contamination and the external surface of the 3WSCs 100\% (Table 1).

Table 1 - Evaluation of bacterial growth on dressing, lumens and external surfaces of the three-way stopcocks used in peripheral venous catheters. Ribeirão Preto, SP, Brazil, 2015

\begin{tabular}{lccc}
\hline \multirow{2}{*}{ Devices } & Bacterial & \multicolumn{2}{c}{$\begin{array}{c}\text { Culture Medium } \\
\text { (Tryptic Soy Broth) }\end{array}$} \\
\cline { 3 - 4 } & Growth & $\mathbf{n}$ & $\%$ \\
\hline Dressing & Present & 26 & 86.7 \\
& Absent & 4 & 13.3 \\
Three-way stopcocks & Present & 12 & 40.0 \\
lumen & Absent & 18 & 60.0 \\
Three-way stopcocks & Present & 30 & 100 \\
external surfaces & Absent & 0 & 0 \\
\hline
\end{tabular}

The length of stay of the PVC ranged from 2 to 8 days: $36.7 \%$ of the samples indicated that the venous catheterization had been done three days ago ( 72 hours) and $26.7 \%$ four days ago (96 hours). The mean and median of the length of stay of the PVC was 3.75 days and three days respectively with a standard deviation of 1.48 .

Additionally, when the presence or absence of macroscopic dirtiness on the devices was analyzed, such as the presence of blood with bacterial growth in a TSB culture medium, it was observed that $46.6 \%$ of these samples were not considered dirty but had a positive culture for bacterial growth, $28 \%$ were considered dirty and showed positive results, $16.7 \%$ were considered dirty but were not positive, and $7.8 \%$ were not considered dirty and also were not positive.

As for the microbiological evaluation of the devices (dressing, lumen, and the external surface of the 3WSCs), 76 bacteria were isolated from the total of 68 positive samples for bacterial growth with the main ones being as follows: coagulase-negative Staphylococcus at $51.3 \%$, Staphylococcus aureus at $12 \%$, Pseudomonas aeruginosa at $9.2 \%$, and Klebsiella pneumoniae at 9.2\% (Figure 1).

Regarding the evaluation of the profile of sensitivity to antibiotics of the bacteria isolated in the positive samples of the dressing, lumen, and external 3WSCS surface, $44 \%, 35.7 \%$, and $73.3 \%$ showed growth of multi-resistant microorganisms, respectively. It should be pointed out that in some samples more than one bacterium was isolated.

Of the total of resistant microorganisms isolated in the samples of the culture from the dressing, the two that stand out the most are coagulase-negative Staphylococcus resistant to methicillin at $91 \%$ and Klebsiella pneumoniae resistant to carbapenems at $9 \%$ (Table 2).

In the lumen of the 3WSCs (Table 3), the one that stands out the most is coagulase-negative Staphylococcus resistant to methicillin at $100 \%$.

Of the total of resistant bacteria isolated in the samples from the external surface of the 3WSCs (Table $4)$, the three that stand out the most are coagulasenegative Staphylococcus with a $72.7 \%$ prevalence, followed by $9 \%$ for Staphylococcus aureus resistant to methicillin, and $9 \%$ for Klebsiella pneumoniae resistant to carbapenems. 


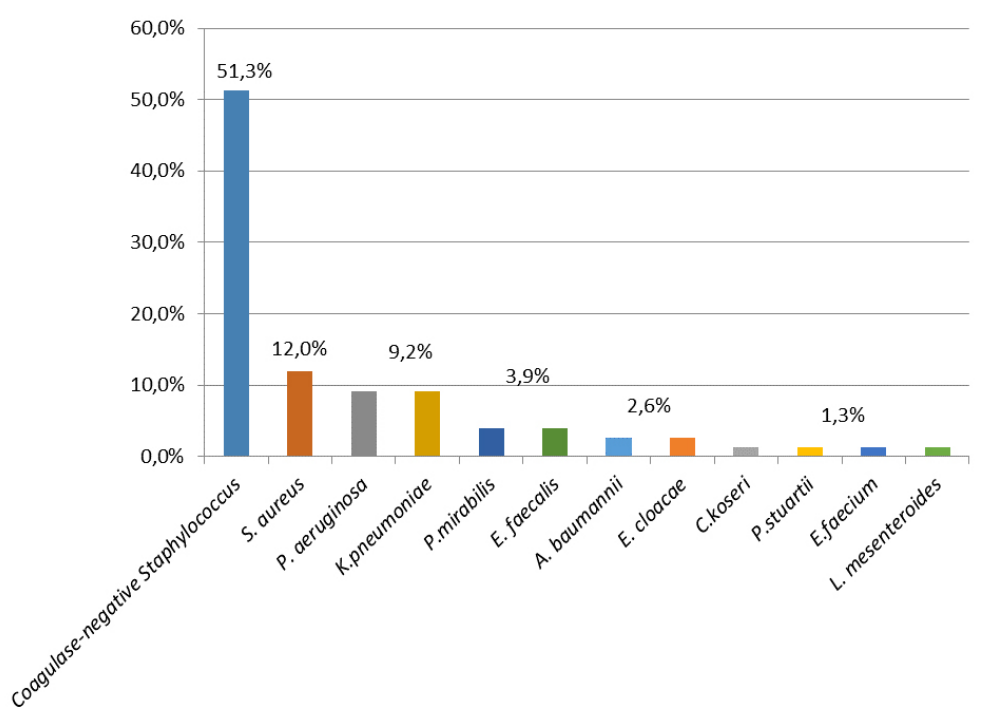

Figure 1 - Evaluation of bacteria distribution in the samples of dressing, lumens and external surfaces of the threeway stopcocks used in peripheral venous catheters. Ribeirão Preto, SP, Brazil, 2015

Table 2 - Evaluation of numerical and percentage distribution of bacteria in dressing used in peripheral venous catheters according to antibiotics sensitivity profile. Ribeirão Preto, SP, Brazil, 2015

\begin{tabular}{|c|c|c|c|c|}
\hline \multirow{3}{*}{ Bacteria } & \multicolumn{4}{|c|}{ Dressing } \\
\hline & \multicolumn{2}{|c|}{ Resistant $(n=11)$} & \multicolumn{2}{|c|}{ Sensitive $(n=14)$} \\
\hline & $\mathbf{n}$ & $\%$ & $\mathbf{n}$ & $\%$ \\
\hline Coagulase-negative Staphylococcus & $10^{*}$ & 91.0 & 3 & 21.4 \\
\hline Pseudomonas aeruginosa & 0 & 0 & 3 & 21.4 \\
\hline Klebsiella pneumoniae & $1^{\dagger}$ & 9.0 & 2 & 14.3 \\
\hline Staphylococcus aureus & 0 & 0 & 2 & 14.3 \\
\hline Enterobacter cloacae & 0 & 0 & 2 & 14.3 \\
\hline Proteus mirabilis & 0 & 0 & 1 & 7.10 \\
\hline Leuconostoc mesenteroides & 0 & 0 & 1 & 7.10 \\
\hline
\end{tabular}

* Methicillin-resistant coagulase-negative Staphylococcus.

+ Carbapenem-resistant Klebsiella pneumoniae.

Table 3 - Evaluation of numerical and percentage distribution of bacteria in lumens of the three-way stopcocks used in peripheral venous catheters according to antibiotics sensitivity profile. Ribeirão Preto, SP, Brazil, 2015

\begin{tabular}{|c|c|c|c|c|}
\hline \multirow{3}{*}{ Bacteria } & \multicolumn{4}{|c|}{3 WSCs* Iumen } \\
\hline & \multicolumn{2}{|c|}{ Resistant $(n=5)$} & \multicolumn{2}{|c|}{ Sensitive $(n=9)$} \\
\hline & $\mathbf{n}$ & $\%$ & $\mathbf{n}$ & $\%$ \\
\hline Coagulase-negative Staphylococcus & $5^{*}$ & 100 & 2 & 22.2 \\
\hline Staphylococcus aureus & 0 & 0 & 2 & 22.2 \\
\hline Pseudomonas aeruginosa & 0 & 0 & 2 & 22.2 \\
\hline Klebsiella pneumoniae & 0 & 0 & 1 & 11.0 \\
\hline Proteus mirabilis & 0 & 0 & 1 & 11.0 \\
\hline Enterococcus faecalis & 0 & 0 & 1 & 11.0 \\
\hline
\end{tabular}

* Methicillin-resistant coagulase-negative Staphylococcus.

Table 4 - Evaluation of numerical and percentage distribution of bacteria in external surfaces of the three-way stopcocks used in peripheral venous catheters according to antibiotics sensitivity profile. Ribeirão Preto, SP, Brazil, 2015

\begin{tabular}{|c|c|c|c|c|}
\hline \multirow{3}{*}{ Bacteria } & \multicolumn{4}{|c|}{ 3WSCs* external surface } \\
\hline & \multicolumn{2}{|c|}{ Resistant $(n=22)$} & \multicolumn{2}{|c|}{ Sensitive $(n=15)$} \\
\hline & $\mathrm{n}$ & $\%$ & $\mathbf{n}$ & $\%$ \\
\hline Coagulase-negative Staphylococcus & $16^{*}$ & 72.7 & 3 & 20.0 \\
\hline Staphylococcus aureus & $2^{*}$ & 9.0 & 3 & 20.0 \\
\hline
\end{tabular}




\begin{tabular}{|c|c|c|c|c|}
\hline \multirow{3}{*}{ Bacteria } & \multicolumn{4}{|c|}{ 3WSCs* external surface } \\
\hline & \multicolumn{2}{|c|}{ Resistant $(n=22)$} & \multicolumn{2}{|c|}{ Sensitive $(n=15)$} \\
\hline & $\mathbf{n}$ & $\%$ & $\mathbf{n}$ & $\%$ \\
\hline Klebsiella pneumoniae & $2^{\dagger}$ & 9.0 & 1 & 6.60 \\
\hline Pseudomonas aeruginosa & $1^{\dagger}$ & 4.5 & 1 & 6.60 \\
\hline Acinetobacter baumannii & $1^{\dagger}$ & 4.5 & 1 & 6.60 \\
\hline Enterococcus faecalis & 0 & 0 & 2 & 13.3 \\
\hline Citrobacter koseri & 0 & 0 & 1 & 6.60 \\
\hline Proteus mirabilis & 0 & 0 & 1 & 6.60 \\
\hline Providencia stuartii & 0 & 0 & 1 & 6.60 \\
\hline Enterococcus faecium & 0 & 0 & 1 & 6.60 \\
\hline
\end{tabular}

* Methicillin-resistant (coagulase-negative Staphylococcus and Staphylococcus aureus).

+ Carbapenem-resistant (Klebsiella pneumoniae, Pseudomonas aeruginosa and Acinetobacter baumannii).

\section{Discussion}

The use of intravascular catheters is one of the important advances in medicine, but we should not be oblivious to the risks inherent in their use, especially infectious events. Some factors that increase the risk of infection are use of the devices, insertion site, length of stay, skin preparation, and type and way of fastening the dressing used(8-10). There is a further concern with the 3WSCs, because beyond being useful in peripheral venous infusions, they also belong to the arsenal of venous extensions.

The literature reveals a low risk of infection of the bloodstream associated with the use of peripheral venous catheters; however, we must consider its high use in health care, a fact that has been changing this scenario( ${ }^{(8)}$. On the other hand, one study ${ }^{(11)}$ demonstrated that the number of bloodstream infections caused by peripheral venous catheters and central venous catheters were similar, and that the peripheral catheters inserted in the emergency department caused the largest number of episodes.

The study evaluated the microbiota, the profile of sensitivity of the bacteria isolated from some devices (dressing, lumens, and external surfaces of the 3WSCS) used in the maintenance of peripheral venous access, the duration of use of the device, and the presence of macroscopic dirtiness.

In the study, microbial growth in the cultures from the external surfaces of the 3WSCs was $100 \%$. Some investigators have speculated that the surface contamination of the 3WSCS occurs due to environmental exposure, manipulation by nursing staff, contact with the patient's microbiota and contact with the bed linen ${ }^{(8,12)}$. Among the resistant bacterial species isolated from the 3WSCS surfaces, the main ones were gram-negative bacteria with a resistance to carbapenems such as Klebsiella pneumoniae (9\%),
Pseudomonas aeruginosa (4.5\%), and Acinetobacter baumannii (4.5\%). Thus, it is important to emphasize that good aseptic practices should be carefully adopted and enforced by the professionals who handle the devices used in the maintenance of the venous catheters in order to avoid contamination of the internal lumen and resultant bloodstream infections ${ }^{(8,10)}$.

At the center of discussions of infection control in health services is the behavior of health professionals, and it is mentioned as an important tool in the implementation of safe practices ${ }^{(1,13)}$. But even though measures to prevent and control bloodstream infection are carefully established by guidelines, the reality of health care points to unsatisfactory levels of compliance by health professionals, especially for the practices of washing hands $(10.7 \%)$ and disinfection of hubs and connectors (40.0\%) prior to drug administration ${ }^{(10,14)}$. It should be noted that connections such as 3WSCs/ hubs and infusion equipment are a common gateway for microorganisms ${ }^{(15)}$. Inadequate disinfection of connectors can result in bacterial contamination of the inner lumen of the catheter, resulting in the formation of biofilm and subsequent bloodstream infection ${ }^{(8)}$. On the other hand, we cannot ignore the possibility that contamination of the catheter's inner lumen may originate in the migration of bacteria inside the catheter coming from the patient's skin and migrating to the catheter's tip.

We consider the contamination rate in the lumen of the 3WSCs $(40 \%)$ to be high and worrisome, especially by resistant bacteria such as coagulase-negative Staphylococcus resistant to methicillin. In general, for hospitalized patients undergoing intravenous therapy, the devices are frequently manipulated to administer drugs at regular intervals; or as is the case with antibiotics, every 6 hours; or analgesics and antipyretics in the case of pain or fever, among other drugs. This fact reinforces 
the need for professionals to adopt safe practices when administering drugs, including meticulous hand hygiene.

Thus, we highlight the importance of disinfecting the hubs and hand hygiene $(\mathrm{HH})$ before and after handling the devices, along with other procedures that impede contamination of the lumen on the 3WSCs. So failure to observe aseptic principles contributes to contaminating the devices.

$\mathrm{HH}$ is the simplest and least expensive individual measure to prevent the spread of healthcare-related infections ${ }^{(6)}$. However, it was not our objective in this study, to determine the frequency of this practice when handling the device.

Furthermore, the lids should be used when closing the 3WSCs, which should be strictly maintained in order to preserve their sterile condition. However, in the real situation of providing care, actions can be taken that contaminate the inside of the lids, such as leaving them on trays or other surfaces with the inner side facing down and then reusing them, when in reality the 3WSCs lids should be discarded with every handling of the device for infusion ${ }^{(10)}$.

Furthermore, we observed that $86.7 \%$ of the culture from the dressing in TSB were positive, which is contrary to our hypothesis. It was speculated that it would be $100 \%$, since dressing are in direct contact with the patient's skin and their endogenous microbiota, and mainly because the sample is collected at the catheter's insertion $^{(11)}$.

The risk became alarming when profile of sensitivity to antibiotics of the species were analyzed; coagulasenegative Staphylococcus resistant to methicillin was at $91 \%$ and Klebsiella pneumoniae resistant to carbapenems was at $9 \%$. It should be noted that perhaps four $(13.3 \%)$ of the negative cultures were associated with the technique of swab collection at just one point (ostium of insertion), duration of use of the dressing, humidity control, and best aseptic practices ${ }^{(16)}$.

The purpose of the dressing is to protect the puncture site and minimize the possibility of infection through the interface between the surface of the catheter and the skin. The dressing should be replaced immediately if contamination is suspected and always when wet, loose, dirty, or with compromised integrity. It is important to protect the insertion site with plastic when showering with a dressing that is not waterproof $f^{(8,10)}$. It should be pointed out that in this study the dressing was waterproof.

In the etiology of hospital infections, the presence of resistant strains has had an impact on morbidity, mortality, and costs, reaching proportions that are very worrisome ${ }^{(3,17)}$. The participation of $S$. aureus resistant to methicillin and of gram-negative bacilli resistant to carbapenems is increasingly frequent in episodes of bacteremia in critically ill patients ${ }^{(18)}$. Thus, another challenging result involved evaluating multidrug-resistant strains and strains with resistance to carbapenems in the maintenance devices of peripheral venous catheters. For decades, the world has witnessed a proliferation of microbes with antibiotic resistance, which implies the acquisition of genes that determine resistance to the point of becoming refractory to virtually all antibiotics, leaving researchers and health professionals in a bleak environment with no therapeutic options. Undoubtedly, one of the most important factors involved is the wide use of antibiotics in outside of hospitals.

Another important point is that in health institutions, the spread of resistant strains is also facilitated by noncompliance with basic recommendations such as washing hands, use of protective barriers, and decontamination of equipment, among other practices ${ }^{(19)}$.

Although there is evidence in literature of low risk of local infection of the bloodstream associated with peripheral venous catheters, this situation is changing ${ }^{(9)}$. For this reason, one should not miss the importance of this issue, especially considering its gravity, the etiology of the microbial species, and the main predisposing factors $^{(20-21)}$. The success of the fight against infection depends not only on accurate diagnosis, but also, and in the same proportion, on improvement of conditions in terms of infrastructure and human resources. As mentioned before, the performance and attitudes of health professionals is relevant. It is necessary to begin to build an educational system that promotes knowledge, skills, and attitudes that are converted into legitimized critical and reflective professional practice. Some of these issues are more acute in countries facing crises in basic conditions of infrastructure, which includes the training of human resources.

The results of the present study encourage a number of reflections, and one is the need to perform essential prospective surveillance to prevent and control hospital infections, thus favoring decision-making based on situations of real care.

This research presents limitations on the reduced size of the samples, which allowed only the analysis of the data by descriptive statistics. On the other hand, the results provide a basis for raising awareness about the importance of following safe practices when providing care for patients with intravenous devices. One result could be the instigation of the development of future clinical research concerned mainly with the relationship among: duration of use of peripheral venous catheters, sensitivity profiles, genetic similarity among the various sample collection locations (3WSCS external surfaces 
and lumens, dressing, and insertion sites), and the biofilm formation on the devices.

\section{Conclusion}

In general, the results are alarming because the contamination by antimicrobial resistant bacteria was identified, and coagulase-negative Staphylococcus resistant to methicillin was predominant in samples from dressing, lumen and the external surface of 3WSCS. Moreover, it is important to emphasize the isolation of gram-negative bacteria resistant to carbapenems on dressing and external surface of 3WSCS, due to the pathogenicity of these microorganisms, which reinforces the importance of nursing care in the maintenance of the biologically safe environment as well as prevention and infection control practices.

\section{References}

1. Rees S, Houlahan B, Safdar N, Sanford-Ring S, Shore $T$, Schmitz M. Success of a multimodal program to improve hand hygiene compliance. J Nurs Care Qual. [Internet]. 2013 [Access Aug 29, 2016];28(4):312-8. Available from: http://journals.Iww.com/jncqjournal/ Abstract/2013/10000/Success_of_a_Multimodal_ Program_to_Improve_Hand.5.aspx. doi: 10.1097/ NCQ.0b013e3182902404

2. Smiddy MP, O' Connell R, Creedon SA. Systematic qualitative literature review of health care workers' compliance with hand hygiene guidelines. Am ] Infect Control. [Internet]. 2015 [Access Aug, 29, 2016];43(3):269-74. Available from: http:// www.sciencedirect.com/science/article/pii/ S0196655314013285. doi: 10.1016/j.ajic.2014.11.007

3. Thaden JT, Lewis SS, Hazen KC, Huslage K, Fowler VG Jr, Moehring RW, et al. Rising rates of carbapenemresistant enterobacteriaceae in community hospitals: a mixed-methods review of epidemiology and microbiology practices in a network of community hospitals in the Southeastern United States. Infect Control Hosp Epidemiol. [Internet]. 2014 [Access Aug 29, 2016];35(8):978-83. Available from: https://www. ncbi.nlm.nih.gov/pmc/articles/PMC4217156/. doi: $10.1086 / 677157$

4. Bardossy AC, Zervos J, Zervos M. Preventing Hospital-acquired Infections in Low-income and Middleincome Countries: Impact, Gaps, and Opportunities. Infect Dis Clin North Am. [Internet]. 2016 [Access Aug 29, 2016];30(3):805-18. Available from: http://www.sciencedirect.com/science/article/pii/ S0891552016300265. doi: 10.1016/j.idc.2016.04.006
5. Folgori L, Bernaschi P, Piga S, Carletti M, Cunha $\mathrm{FP}$, Lara $\mathrm{PH}$, et al. Healthcare-associated Infections in Pediatric and Neonatal Intensive Care Units: Impact of Underlying Risk Factors and Antimicrobial Resistance on 30-Day Case-Fatality in Italy and Brazil. Infect Control Hosp Epidemiol. [Internet]. 2016 [Access Aug 29, 2016];11:1-8. Available from: http://journals. cambridge.org/action/displayAbstract?fromPage =onli ne\&aid $=10467817$ \&fileId $=$ S0899823X16001859. doi: $10.1017 /$ ice. 2016.185

6 . Lorente $L$. What is new for the prevention of catheterrelated bloodstream infections? Ann Transl Med. [Internet]. 2016 [Access Aug 29, 2016];4(6):119. Available from: https://www.ncbi.nlm.nih.gov/pmc/ articles/PMC4828748/. doi: 10.21037/atm.2016.03.10 7. Garcia RA, Spitzer ED, Beaudry J, Beck C, Diblasi R, Gilleeny-Blabac $M$, et al. Multidisciplinary team review of best practices for collection and handling of blood cultures to determine effective interventions for increasing the yield of true-positive bacteremias, reducing contamination, and eliminating false-positive central line-associated bloodstream infections. Am J Infect Control. [Internet]. 2015 [Access Aug 29, 2016];43(11):1222-37. Available from: http://www.sciencedirect.com/science/article/pii/ S0196655315007488. doi: 10.1016/j.ajic.2015.06.030 8. O'Grady NP, Alexander M, Burns LA, Dellinger EP, Garland J, Heard SO, et al. Guidelines for the prevention of intravascular catheter-related infections. Am J Infect Control. [Internet]. 2011 [Access Aug 29, 2016];39(4 Suppl 1):S1-34. Available from: https://www.ncbi.nlm. nih.gov/pmc/articles/PMC3106269/. doi: 10.1093/cid/ cir257

9. Bernatchez S. Care of Peripheral Venous Catheter Sites: Advantages of Transparent Film Dressings Over Tape and Gauze. JAVA. [Internet]. 2014 [Access Aug 29, 2016];19(4):256-61. Available from: http://www.sciencedirect.com/science/article/pii/ S1552885514001615. doi: 10.1016/j.java.2014.09.001 10. Ministério da Saúde. Agência Nacional de Vigilância Sanitária. Medidas de prevenção de infecção relacionada à assistência à saúde. Brasília: Ministério da Saúde;2013. 92 p. [Internet]. [Acesso 29 ago 2016]. Disponível em: http://www20.anvisa.gov.br/ segurancadopaciente/images/documentos/livros/ Livro4-MedidasPrevencaoIRASaude.pdf

11. Pujol M, Hornero A, Saballs M, Argerich MJ, Verdaguer R, Cisnal M, et al. Clinical epidemiology and autcomes of peripheral venous catheter-related bloodstream infections at a university-affiliated hospital. 3 Hosp Infect. [Internet]. 2007 [Access Aug 29, 2016];67(1):22-9. Available from: http://www.sciencedirect.com/science/ article/pii/S0195670107002228. doi: 10.1016/j. jhin.2007.06.017 
12. Rosenthal VD, Udwadia FE, Kumar S, Poojary A, Sankar R, Orellano PW, et al. Clinical impact and cost-effectiveness of split-septum and singleuse prefilled flushing device vs 3-way stopcock on central line-associated bloodstream infection rates in India: a randomized clinical trial conducted by the International Nosocomial Infection Control Consortium (INICC). Am J Infect Control. [Internet]. 2015 [Access Aug 29, 2016];43(10):1040-5. Available from: http://www.sciencedirect.com/science/article/pii/ S0196655315006550. doi: 10.1016/j.ajic.2015.05.042

13. Ferreira AM, Andrade Dd, Haas VJ. Microbial contamination of procedure gloves after opening the container and during exposure in the environment = Contaminação microbiana das luvas de procedimento após a abertura da caixa e durante sua exposição ambiental = Contaminación microbiana de guantes de procedimiento luego de la abertura de la caja y durante exposición ambiental. Rev Esc Enferm USP. [Internet]. 2011 [Acesso 29 ago 2016];45(3):745-50. Disponível em: $\quad$ http://www.scielo.br/scielo.php?script=sci_ arttext\&pid=S0080-62342011000300028\&Ing $=e n \& n r m=i s o \& t \operatorname{lng}=e n$. doi: 10.1590/S008062342011000300028 English, Portuguese, Spanish.

14. Jardim JM, Lacerda RA, Soares Nde J, Nunes BK. [Evaluation of practices for the prevention and control of bloodstream infections in a government hospital]. Rev Esc Enferm USP. [Internet]. 2013 [Access Ago 29, 2016];47(1):38-45. Available from: http://www. scielo.br/scielo.php?script $=$ sci_arttext\&pid $=$ S0080$62342013000100005 \& \operatorname{lng}=e n \& n r m=i s o \& \operatorname{lng}=e n$. doi: 10.1590/S0080-62342013000100005.

15. Loftus RW, Brindeiro BS, Kispert DP, Patel HM, Koff $M D$, Jensen JT, et al. Reduction in intraoperative bacterial contamination of peripheral intravenous tubing through the use of a passive catheter care system. Anesth Analg. [Internet]. 2012 [Access Aug 29, 2016];115(6):131523. Available from: http://journals.Iww.com/anesthesiaanalgesia/pages/articleviewer. aspx ?year $=2012$ \&issue $=12000$ \&article $=00011$ \&type $=$ abstract. doi: 10.1213/ ANE.0b013e31826d2aa4

16. Brito CS. Etiologia e patogênese de infecções de corrente sanguínea associada ao uso de cateter vascular central de longa duração em pacientes submetidos à cirurgia gastrointestinal. [Internet]. Uberlândia (MG): Universidade Federal de Uberlândia; 2006 [Acesso 29 ago 2016]. 59 p. Disponível em: https://repositorio.ufu. br/handle/123456789/16642

17. de Kraker ME, Jarlier V, Monen JC, Heuer OE, van de Sande N, Grundmann $H$. The changing epidemiology of bacteraemias in Europe: trends from the European Antimicrobial Resistance Surveillance System. Clin Microbiol Infect. [Internet]. 2013 [Access Aug 29, 2016];19(9):860-8. Available from: http://www.sciencedirect.com/science/article/pii/ S1198743X14632079. doi: 10.1111/1469-0691.12028

18. Curcio D; Latin American Antibiotic Use in Intensive Care Unit Group. Antibiotic prescriptions in criticallyill patients: a Latin American experience. Ann Med Health Sci Res. [Internet]. 2013 [Access Aug 29, 2016];3(2):220-8. Available from: https://www. ncbi.nlm.nih.gov/pmc/articles/PMC3728867/. doi: 10.4103/2141-9248.113666

19. Haas JP, Shupper $P$, Visintainer $P$, Montecalvo MA. Evaluation of contact precautions discharges in an acute care setting. Am J Infect Control. [Internet]. 2012 [Access Aug 29, 2016];40(5):468-9. Available from: http://www.sciencedirect.com/science/article/pii/ S0196655311009710. doi: 10.1016/j.ajic.2011.07.010 20. Webster J, Osborne S, Rickard CM, New K. Clinicallyindicated replacement versus routine replacement of peripheral venous catheters. Cochrane Database Syst Rev [Internet]. 2015 [Access Aug 29, 2016];(8):CD007798. Available from: http://onlinelibrary.wiley.com/ doi/10.1002/14651858.CD007798.pub4/full. doi: 10.1002/14651858.CD007798.pub4

21. Rickard CM, Webster J, Wallis MC, Marsh N, McGrail $M R$, French $V$, et al. Routine versus clinically indicated replacement of peripheral intravenous catheters: a randomised controlled equivalence trial. Lancet. [Internet] . 2012 [Access Aug 29, 2016];380(9847):106674. Available from: http://www.sciencedirect.com/ science/article/pii/S0140673612610824. doi: 10.1016/ S0140-6736(12)61082-4
Corresponding Author:

Evandro Watanabe

Universidade de São Paulo. Faculdade de Odontologia de Ribeirão Preto

Av. do Café, $s / n$

Bairro: Monte Alegre

CEP: 14040-904, Ribeirão Preto, SP, Brasil

E-mail: evandrowatanabe@gmail.com
Received: Mar. 22 2016 Accepted: Feb. $21^{\text {st }} 2017$
Copyright $(2017$ Revista Latino-Americana de Enfermagem This is an Open Access article distributed under the terms of the Creative Commons (CC BY).

This license lets others distribute, remix, tweak, and build upon your work, even commercially, as long as they credit you for the original creation. This is the most accommodating of licenses offered. Recommended for maximum dissemination and use of licensed materials. 